\title{
PERBANDINGAN AKUNTANSI MUDLÂRABAH MUTHLAQAH DAN MUSYTARAKAH DALAM PERBANKAN SYARI'AH
}

\author{
Sri H andayani \\ (D osen Program Studi Perbankan Syariah Jurusan Syariah STA IN Pamekasan)
}

\begin{abstract}
A bstract:
In business, transaction records is very important. An accurate accounting record displays the true description of a business, nevertheless, it must anticipate a public norm. It has been stated on the Holy Quran at verse of al-Baqarah (2): 282 that the command of adminstration order, and transparancy, have been repeated for about five times. This is about to darify how the accounting treatment of mudlârabah muthlaqah and mudlârabah musytarakah must be written. The both have a distinctive caharacters that must be separated to each other to figure out the correct portion of devidend based on the applied agreement. M udlârabah muthlaqah is a mudlârabah-base management, the investor gives an authority in financial management. Meanwhile, mudlârabah musyatarakah has been the combination of mudlârabah and musyarakah
\end{abstract}

\section{Key Words:}

A kuntansi, mudlârabah, mudlârabah mutlaqah, dan mudlârabah musytarakah

\section{Pendahuluan}

Berbicara tentang akuntansi, orang akan berfikir mengenai angka-angka yang berada dalam laporan keuangan. Dengan melihat laporan keuangan, maka akan diketahui keadaan dari suatu usaha apakah perusahaan tersebut berada pada keadaan maju atau tidak. Adanya laporan keuangan yang sesuai dengan kaidah umum maka semua orang mempunyai pemikiran yang sama terhadap laporan tersebut. Laporan yang benar akan memberikan pandangan yang akan dijadikan sebagai dasar untuk membuat perencanaan di masa yang akan datang. Sebuah laporan keuangan diperoleh dari pencatatan akuntansi yang dimulai dari pencatatan transaksi, 
Sri Handayani

pengklasifikasian dan peringkasan yang akhirnya akan menghasilkan sebuah laporan keuangan. Laporan keuangan tersebut dapat digunakan sebagai acuan dalam pembuat keputusan bagi pihak perusahaan maupun pihak ekstern seperti pemerintah dalam hal pajak dan investor yang menginvestasikan dananya dalam perusahaan.

Pentingnya sebuah laporan keuangan untuk kelangsungan hidup perusahaan atau usaha tersebut, maka dalam pembuatan laporan keuangan harus berdasarkan bukti-bukti transaksi yang benar bukan bukti spekulatif. Semua transaksi, terutama transakti future delivery harus ditulis secara bagus dan detail.1 Tradisi pencatatan transaksi akuntansi yang sangat bagus telah dilakukan oleh sahabat Ibn Tsabit dengan menggunakan double entry system dalam administrasi Diwân Bayt al-M âl beratus tahun sebelum Lucas Facioli dari Italia.2

Dengan melihat pentingnya laporan keuangan melalui prilaku akuntansi yang benar, maka tulisan ini mencoba menjelaskannya tetapi pembatasan pada bagaimana prilaku akuntansi mudlârabah muthlaqah dan mudlârabah musyarakah, karena dalam bentuk tersebut mempunyai perbedaan yang siqnifikan dalam pencatatan akuntansinya meskipun mempunyai persamaan yang sama pada awal transaksi yaitu sama-sama menggunakan akad mudlârabah. Adanya perbedaan tersebut maka perlu dianalisis bagaimana penerapan pencatatan tersebut agar menjadi jelas dan tidak terdapat kerancuan dalam pelaporannya.

\section{Akuntansi Syarî'ah di Indonesia}

Perkembangan akuntansi syarî'ah di Indonesia mulai terasa sejak adanya krisis moneter 1997 karena hanya bank yang berbentuk syarî'ah yang masih tetap bertahan sampai sekarang sebagai contoh Bank Muamalat Indonesia yang mampu menahan goncangan dari krisis tersebut. Perkembangan akuntansi ini telah dilakukan pada tingkatan nasional pada tahun 2003 dengan adanya PSAK (Pedoman

\footnotetext{
1 Iwan triyuwono, Perspektif M etodologi dan Teori A kuntansi Syariah, (Jakarta:PT Raja Grafindo Persada, 2006), hlm.vii

2 Ibid.
} 
Standar Akuntansi) No 59 dibuat dengan merujuk pada standar Akuntansi Syariah Internasioal Accounting and Auditing Standars for islamic Financial Institutions yang dibuat Accounting and Auditing Organization for Islamic Financial Institutions (AAOIFI), dan telah diperluas lagi pada PSAK per Juli tahun 2009 dengan pasal $101 \mathrm{~s} / \mathrm{d}$ 108. Pasal-pasal tersebut meliputi penyajian laporan akuntansi syarî'ah, akuntansi murâbahnah, akuntansi salam, akuntansi istisna', akuntansi mudlarabah, akuntansi musyarakah, akuntansi ijârah, dan akuntansi transaksi asuransi syarî'ah.

Transaksi-taransaksi dalam dunia usaha banyak sekali sehingga perlu pencatatan yang sesuai dengan prilakunya seperti jika perusahaan membeli mesin secara tunai maka akan timbul penambahan mesin dalam aktiva dan kas akan berkurang. Begitu juga dalam hal penanaman modal usaha. Dalam penyertaan modal tersebut akad apakah yang seharusnya dipakai agar dapat diketahui dengan jelas sistem bagi hasil dari investasi modal tersebut dan laporan keuangan perusahaan yang benar. Adanya kesalahan dalam pencatatan akuntansi akan membawa dampak laporan keuangan yang kurang jelas dan pada akhirnya jika laporan tersebut digunakan sebagai acuan dalam membuat keputusan untuk langkah rencana maka akan menjadi bumerang di masa yang akan datang.

\section{Konsep D asar A kuntansi}

Akuntansi, seperti didefinisikan oleh American institute of certified Public Accountants (AICPA), adalah suatu kegiatan jasa. Fungsinya adalah menyediakan data kuantitatif, terutama yang mempunyai sifat keuangan, dari kesatuan usaha ekonomi yang dapat digunakan dalam pengambilan keputusan-keputusan ekonomi dalam memilih alternatif-alternatif dari suatu keadaan. ${ }^{3}$ Sedangkan menurut Nikolai and Bazley, akuntansi mungkin saja bisa digambarkan sebagai suatu proses pengidentifikasian, pengumpulan dan pengelompokan serta memberikan informasi ekonomi yang dapat dijadikan sebagai pertimbangan dalam pengambilan keputusan oleh pengguna informasi tersebut. Sementara menurut Wiroso, akuntansi

3 AICPA, Statement of the A ccounting Principles Board, Nomor 4, (New York: Oktober, tt.), hlm. 17. Lihat juga dalam Zaki Baridwan, Intermediet accounting, (Yogyakarta: BPFE, 2005) hlm.1 
Sri Handayani

adalah suatu sistem informasi yang mengidentifikasi, mencatat, serta mengkomunikasikan transaksi ekonomi yang terjadi pada suatu organisasi kepada pihak yang berkepentingan. ${ }^{4}$ Dari ketiga definisi tersebut, kegiatan akuntansi dapat dibagi menjadi tiga kegiatan yaitu pencatatan, pengelompokan dan peringkasan yang akhirnya menghasilkan laporan keuangan untuk digunakan perusahaan maupun pihak luar dalam membuat keputusan ekonomi dalam memilih alternatifnya5.

Laporan keuangan merupakan bagian dari proses pelaporan keuangan. Laporan yang lengkap meliputi neraca, laporan laba rugi, laporan perubahan posisi keuangan catatan dan laporan lainnya serta materi penjelasan yang merupakan bagian intergral dari laporan keuangan. Tujuan dari laporan keuangan itu sendiri adalah menyediakan informasi yang menyangkut posisi keuangan, kinerja, serta perubahan posisi keuangan suatu perusahaan yang bermanfaat bagi sejumlah besar pengguna dalam pengambilan keputusan ekonomi. ${ }^{6}$

Untuk penyusunan laporan agar dapat menyediakan data dalam pengambilan keputusan maka dibutuhkan prinsip akuntansi yang berlaku umum. Dalam penyusunan prinsip akuntansi didasarkan pada asumsi-asumsi dan konsep-konsep dasar. Adapun asumsi dasar akuntansi yaitu dasar akrul dan kelangsungan usaha. Dasar akrual adalah pengaruh transaksi dan peristiwa lain diakui pada saat kejadian (dan bukan pada saat kas atau setara kas diterima atau dibayar) dan dicatat dalam catatan akuntansi serta dilaporkan dalam laporan keuangan pada periode yang bersangkutan.7

Sedangkan asumsi kelangsungan usaha adalah bahwa perusahaan diasumsikan tidak bermaksud atau berkeinginan melikuidasi atau mengurangi secara material skala usahanya. Jika maksud atau keinginan tersebut timbul, laporan keuangan mungkin

\footnotetext{
4 Wiroso, Pengantar A kuntansi Syariah dan Laporan Keuangan Bank Syariah, makalah pada TOT Perbankan Syariah UNAIR tahun 2010, hlm.2

5 Mulyadi, Sistem A kuntansi, ( Jakarta: Salemba Empat, 2001), hlm. 3

6 IAI, Standar A kuntansi Keuangan, (Jakarta: Salemba Empat, 2009), hlm 3

$7 \mathrm{lbid}, \mathrm{hlm} 5$
} 
harus disusun dengan dasar yang berbeda dan dasar yang digunakan harus diungkapkan. ${ }^{8}$

\section{Karakteristik Kualitatif Laporan Keuangan}

Karakteristik kualitatif merupakan ciri khas yang membuat laporan keuangan berguna bagi pengguna. Adapun karakteristik kualitatif harus meliputi empat hal, yaitu dapat dipahami, relevan, keandalan, dan dapat diperbandingkan. Dapat dipahami adalah kualitas penting informasi yang ditampung, dalam laporan keuangan adalah kemudahannya untuk segara dapat dipahami oleh pengguna. Relevan maksudnya yaitu untuk memenuhi kebutuhan pengguna dalam proses pengambilan keputusan. Informasi memiliki kualitas relevan kalau dapat mempengaruhi keputusan ekonomi pengguna dengan membantu mereka mengevaluasi peristiwa masa lalu, masa kini atau masa depan, menegaskan atau mengoreksi, hasil evaluasi pengguna di masa lalu. Keandalan maksudnya adalah informasi memiliki kualitas andal jika bebas dari pengertian yang menyesatkan. Dan dapat dibandingkan maksudnya yaitu pengguna harus dapat memperbandingkan laporan keuangan perusahaan antar periode untuk mengidentifikasi kecenderungan (trend) posisi dan kinerja keuangan. ${ }^{9}$

Suatu laporan keuangan yang berdasarkan keempat pokok tersebut diharapkan dapat harapan yang dinginkan oleh pengguna informasi keuangan dalam pengambilan keputusan. Sebagai contoh bahwa data tersebut tidak relevan jika keabsahan masih dipersengketakan, mungkin tidak tepat bagi perusahaan untuk mengakui jumlah seluruh tuntutan tersebut dalam neraca, meskipun mungkin tepat untuk mengungkapkan jumlah serta keadaan dari tuntutan tersebut.

\section{Tujuan Sistem Keuangan Islam}

Seperti dalam bagian pendahuluan dijelaskan bahwa Bank Muamalat Indonesia yang berdiri tahun 1992 dapat bertahan dan tidak mengalami likuidasi ketika terjadi krisis keuangan global pada

\footnotetext{
8 Ibid.

$9 \mathrm{lbid}, \mathrm{hlm} .5$ - 8
} 
Sri Handayani

tahun 1997. Bertahannya bank tersebut karena sistem kerjanya berdasarkan sistem bagi hasil dan tidak berdasarkan bunga yang biasanya terjadi pada bank konvensional. Sistem keuangan dalam perbankan Islam memberikan jasa keuangan yang dapat diterima secara religius pada komunitas-komunitas Islam pada awalnya. Akan tetapi perkembangannya saat ini bank konvesional lainnya telah mulai mengincar prospek dari bank yang berbasis syarî'ah tersebut. Bank-bank nasional yang ada di Indonesia telah mempunyai unit-unit syarî'ah sebagai contoh Bank Negara Indonesia, Bank Rakyat Indonesia, Bank Jatim dan masih banyak lagi bank konvensional yang mempunyai unit usaha syarî'ah. Karena itu, bank yang berbais syarî'ah, selain aspek religius, dapat memberikan kontribusi secara pantas kepada pencapaian tujuan-tujuan sosio-ekonomi Islam yang utama.10 Maksud dari pernyataan tersebut adalah memberikan kesejahteraan ekonomi yang meningkat dengan memberikan kesempatan pekerjaan sehingga pertumbuhan ekonomi menjadi tinggi. Aspek religius seharusnya dikemukakan untuk melakukan operasi-operasi keuangan yang sah secara agama yang nota bene mempunyai nilai lebih benar jauh melampaui nilai model keuangan itu sendiri.11

Adapun tujuan utama perbankan dan keuangan Islam dari perpektif Islam adalah: Pertama, penghapusan bunga dari semua transaksi keuangan dan pembaharuan semua aktivitas bank agar sesuai dengan prinsip-prinsip Islam; kedua, pencapaian distribusi pendapatan dan kekayaan yang wajar; ketiga, promosi pembangunan ekonomi.12 Selain tujuan tersebut, transaksi syarî'ah mempunyai asas yang berdasarkan pada prinsip: Pertama, prinsip persaudaraan (ukhuwah ) Yang esensinya merupakan nilai universal yang menata interaksi sosial dan harmonisasi kepentingan para pihak untuk kemanfaatan secara umum dengan semangat saling tolong menolong. Kedua, prinsip keadilan ('adalah) yang esensinya menempatkan sesuatu hanya pada tempatnya dan memberikan sesuatu hanya pada yang berhak serta memperlakukan sesuatu sesuai posisinya. Ketiga,

10 Latifa M. Algaoud dan Mervyn K. Lewis, Perbankan Syariah: Prinsip, Praktik, Prospek ", (Jakarta: Serambi, 2005), hlm. 134

11 Ibid., hlm. 135

12 Ibid. 
prinsip kemaslahatan (mashlahah) esensinya merupakan segala bentuk kebaikan dan manfaat yang berdemensi duniawi dan ukhrawi, material dan spiritual, serta individual dan kolektif. Keempat, prinsip keseimbangan (tawâzun) esensinya meliputi keseimbangan aspek material dan spiritual, aspek privat dan publik, sektor keuangan dan sektor riil, bisnis dan sosial dan keseimbangan aspek pemanfaatan dan pelestarian. Kelima, prinsip universalisme (syumuliyah) esensinya dapat dilakukan oleh, dengan dan untuk semua pihak yang berkepentingan (stakeholder) tanpa membedakan suku, agama, ras dan golongan sesuai dengan semangat kerehmatan semesta (rahmatan li alalamîn). ${ }^{13}$ Prinsp-prinsip tersebut senantiasa selalu ada dalam setiap nafas transaksi syarî'ah sehingga tujuan dari kegiatan ekonomi tersebut memperoleh kebaikan untuk diri dan masyarakat secara luas.

Karakteristik transaksi syarî'ah adalah suatu transaksi yang hanya dilakukan berdasarkan prinsip saling paham dan saling ridha, prinsip kebebasan bertransaksi diakui sepanjang objeknya halal dan baik (thayib), uang hanya berfungsi sebagai alat tukar dan satuan pengukur nilai, bukan sebagai komoditas, tidak mengandung unsur ribâ, kezaliman, maysîr, gharar.14 Sedangkan transaksi syarî'ah berbentuk dua yaitu komersial berupa investasi untuk mendapatkan bagi hasil, jual beli untuk mendapatkan laba serta pemberian layanan jasa untuk mendapatkan imbalan. Sedangkan transaksi syarî'ah berbentuk non komersial yang berupa pemberian dana pinjaman atau talangan ( $q a r d l)$, penghimpunan dan penyaluran dana sosial seperti infak, sedekah, wakaf dan hibah.

\section{Cakupan Akuntansi Mudlârabah}

A kad mudlârabah yaitu akad kerjasama usaha antara dua pihak di mana pihak pertama (pemilik dana) menyediakan seluruh dana, sedangkan pihak kedua (pengelola dana) bertindak selaku pengelola, dan keuntungan dibagi di antara mereka sesuai kesepakatan sedangkan kerugian finansial hanya ditanggung oleh pemilik dana. ${ }^{15}$ Adapun karakteristik akuntansi mudlârabah adalah entitas dapat bertindak baik sebagai pemilik dana maupun pengelola dana.

\footnotetext{
13|AI, Standar, hlm. 4-5

${ }^{14}$ Ibid., hlm. 5 - 7

$15 \mathrm{Ibid} ., \mathrm{hlm} .1$
} 
Sri Handayani

Sedangkan jenis mudlârabah terdiri atas: Pertama, mudlârabah mutlhlaqah, yaitu pemilik dana memberikan kuasa penuh dalam pengelolaan dana. Kedua, mudlârabah muqayyadah, yaitu pemilik dana memberikan batasan atau syarat dalam pengelolaan dana mengenai tempat cara dan atau objek investasi contohnya tidak mencampurkan dana pemilik dana dengan dana lainnya atau mengharuskan pengelola dana untuk melakukan investasi sendiri tanpa melalui pihak ketiga. Ketiga, mudlârabah musytarakah adalah dimana pengelola dana menyertakan modal atau dananya dalam kerjasama investasi. ${ }^{16}$

Prinsip pembagian hasil usaha mudlârabah dapat dilakukan berdasarkan prinsip bagi hasil atau bagi laba. Dalam prinsip bagi hasil, dasar pembagian hasil usaha adalah laba bruto bukan total pendapatan usaha (omzet). Sedangkan dalam prinsip bagi laba, dasar pembagiannya adalah laba netto yaitu laba bruto dikurangi beban yang berkaitan dengan pengelolaan dana mudlârabah.

Pembagian hasil usaha mudlqrabah dibagi sesuai nisbah yang disepakati pada awal akad antara pemilik dana dan pengelola dana. Pada prinsipnya dalam penyaluran mudlârabah tidak ada jaminan, namun agar pengelola dana tidak melakukan penyimpangan maka pemilik dana meminta jaminan dari pengelola dana atau pihak ketiga. Jaminan ini hanya dapat dicairkan apabila pengelola dana terbukti melakukan pelanggaran terhadap hal-hal yang telah disepakati bersama dalam akad. Sedangkan pengembalian dana mudlârabah dapat dilakukan bertahap bersamaan dengan distribusi bagi hasil atau secara total pada saat akad mudlârabah selesai. ${ }^{17}$

Dalam pembiayaan mudlârabah, modal adalah uang atau asset yang diberikan oleh shâhib al-mâl kepada mudlârib untuk tujuan usaha dengan syarat harus diketahui jumlah dan jenisnya yang harus dinilai pada waktu akad, tidak berbentuk piutang dan harus dibayarkan kepada mudlârib. 18

\footnotetext{
16 Ibid.

17 Ibid., hlm 2

18 Wiroso, Pengantar A kuntansi Syariah dan Laporan Keuangan Bank Syariah, hlm.20
} 
P erbandingan P erlakuan A kuntansi

\section{Perlakuan A kuntansi Mudlqrabah}

Perlakuan akuntansi mudlârabah meliputi akuntansi pemilik dana dan akuntansi pengelola dana sesuai PSAK 105. Untuk Akuntansi pemilik dana, perlakuan akuntansinya, yaitu: Pertama, saat dana mudlârabah diterima maka diakui sebagai investasi mudlârabah. Kedua, investasi mudlârabah jika berbentuk kas maka diukur sebesar jumlah yang dibayar, sedangkan jika berbentuk asset diukur sebesar nilai wajar saat penyerahan (nilai wajar > nilai tercatatnya diakui $\Rightarrow$ selisihnya diakui sebagai keuntungan tangguhan dan diamortisasi sesuai jangka waktu akad mudlârabah, dan jika nilai wajar < nilai tercatatnya $\Rightarrow$ selisihnya diakui sebagai kerugian. Ketiga, jika nilai investasi mudlârabah turun sebelum usaha dimulai disebabkan rusak atau faktor lain bukan kesalahan pengelola dana maka penurunan nilai tersebut diakui sebagai kerugian dan mengurangi saldo investasi mudlârabah. Keempat, jika sebagian investasi tersebut hilang setelah dimulai usaha maka kerugian diperhitungkan pada saat bagi hasil. Kelima, usaha mudlârabah diakui pada saat usaha tersebut dijalankan, Keenam, jika aset nonkas mengalami penurunan nilai pada saat atau setelah barang dipergunakan maka kerugian tidak langsung mengurangi jumlah investasi namun diperhitungkan pada saat pembagian bagi hasil. Ketujuh, kelalaian atau kesalahan pengelola ditunjukkan oleh persyaratan yang ditentukan dalam akad tidak terpenuhi, tidak terdapat kondisi diluar kemampuan yang lazim atau yang telah ditentukan dalam akad dan hasil keputusan dari instansi yang berwenang. Kedelapan, jika akad mudlârabah berakhir sebelum atau saat akad jatuh tempo dan belum dibayar oleh pengelola dana maka investasi tersebut diakui sebagai piutang. Kesembilan, jika investasi tersebut melewati satu periode pelaporan maka penghasilan diakui dalam periode terjadinya hak bagi hasil sesuai nisbah yang disepakati. Kesepuluh, kerugian terjadi sebelum akad mudlârabah berakhir diakui sebagai kerugian sehingga membentuk kerugian investasi. Kesebelas, pengakuan penghasilan ini dapat diketahui berdasarkan bagi hasil atas penghasilan usaha dari pengelola dana serta dilarang melakukan pengakuan pendapatan dari proyeksi hasil usaha. K eduabelas, kerugian atas kelalaian pengelola dana dibebankan pada pengelola dana dan tidak mengurang investasi mudlârabah. 
Sri Handayani

Ketigabelas, jika bagian hasil usaha belum dibayar oleh pengelola dana maka diakui sebagai piutang.

Sedangkan untuk akuntansi pengelola dana, perlakuan akuntansinya adalah: Pertama, dana yang diterima dari pemilik dana dalam akad mudlârabah diakui sebagai dana syirkah temporer sebesar jumlah kas atau nila wajar non kas yang diterima dan pada akhir periode dana tersebut diukur sebesar nilai tercatatnya. Kedua, dana yang diterima diakui sebagai aset pada saat pembayaran kas atau penyerahan aset non kas. Ketiga, pengelola dana mengakui pendapatan tas penyaluran dana syirkah temporer secara bruto sebelum dikurangi bagian hak pemilik dana. Keempat, hak bagi pihak ketiga atas bagi hasil dana syirkah temporer yang sudah diperhitungkan tetapi belum dibagikan kepada pemilik dana diakui sebagai kewajiban sebesar bagi hasil yang menjadi porsi hak pemilik dana. Kelima, kerugian yang diakibatkan oleh kesalahan pengelola dana diakui sebagai beban pengelola dana.

Untuk memberikan penjelasan yang konkrit dari perlakuan akuntansi tersebut maka akan dijelaskan dengan contoh dari sebuah transaksi sebagai berikut: " Tuan Iqbal disetujui dari Bank Amanah untuk diberikan modal mudlârabah sebesar Rp. 2.000 .000 yang disepakati nisbah sebesar 40 untuk bank dan 60 untuk mudlârib" .

\begin{tabular}{|c|c|c|}
\hline Catatan akuntansi Pemilik dana & Transaksi & $\begin{array}{c}\text { Pengelola dana } \\
\text { (mudlarib) }\end{array}$ \\
\hline $\begin{array}{c}\text { Kontra kewajiban inv mud Rp 2.000.000,- } \\
\text { Kewajiban komitment Rp 2.000.000,- }\end{array}$ & $\begin{array}{l}\text { Pada saat disetujui } \\
\text { investasi mudlârabah }\end{array}$ & Tidak ada jurnal \\
\hline $\begin{array}{l}\text { Investasi mudlarabah } \mathrm{Rp} 2.000 .000,- \\
\text { Rekening mudlarib Rp 2.000.000,- } \\
\text { kewajiban inv mudlarabah Rp } 2.000 .000,- \\
\text { Kontra kewajiban komitment Rp } \\
\text { 2.000.000,- }\end{array}$ & $\begin{array}{l}\text { Pada saat } \\
\text { pembayaran dana }\end{array}$ & $\begin{array}{l}\text { Kas Rp. } 2.000 .000 \text {, } \\
\text { Dana syirkah temporer } \\
\text { Rp 2.000.000,- }\end{array}$ \\
\hline Jurnal pembentukan cadangan kerugian & $\begin{array}{l}\text { M udlarib mengal ami } \\
\text { rugi Rp } 100.000,- \\
\text { tetapi tidak karena } \\
\text { kelalainnya }\end{array}$ & $\begin{array}{l}\text { Tidak ada jurnal, } \\
\text { kerugian ditanggung } \\
\text { pemilik modal sesuai } \\
\text { PSAK no } 105 \text { pasal } 4\end{array}$ \\
\hline $\begin{array}{l}\text { Beb penyisihan kerug inv mudl } \mathrm{Rp} 100.000 \\
\text { A km penyisihan kerug inv mudl } \mathrm{Rp} \\
100.000,- \\
\text { Jurnal pada saat penghapusan buku }\end{array}$ & & \\
\hline
\end{tabular}




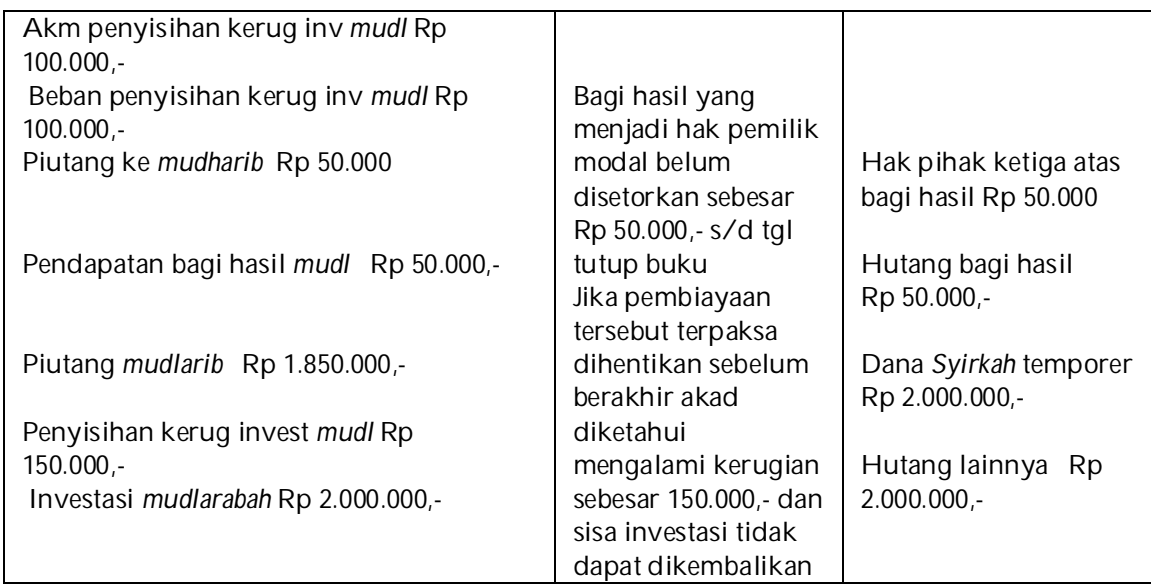

\section{Perlakuan Akuntansi Mudlarabah Muthlaqah dan M usytarakah}

Menurut karakteristiknya akuntansi mudlarabah terbagi menjadi 3 (tiga) baik sebagai pemilik dana maupun pengelola dana, yaitu mudlârabah muthlaqah, mudlârabah muqayadah dan mudlârabah musytarakah. Perbedaan mendasar hanya terjadi antara mudlârabah muthlaqah dan mudlârabah musytarakah. Sedangkan antara mudlârabah muthlaqah dan mudlârabah muqayadah hanya berbeda pada pemberian kuasa penuh dan pemberian batasan dalam pengelolaan dananya saja.

Sementara dalam mudlârabah musytarakah, pihak pengelola dana memasukan modalnya dalam investasi tersebut sehingga dalam perlakuan akuntansi mudlârabah musytarakah perlu dilakukan pemisahan. Karena itu, dalam pembagian hasil investasi mudlarabah musytarakah dapat dilakukan; pertama, hasil investasi di bagi antara pengelola dana (mudlârib) dan pemilik dana sesuai dengan nisbah yang disepakati, selanjutnya bagian hasil investasi setelah dikurangi untuk pengelola dana (sebagai mudlârib) tersebut dibagi antara pengelola dana (musyatarik) dengan pemilik dana sesuai dengan porsi modal masing-masing, dan kedua, hasil investasi dibagi antara pengelola dana (sebagai musytarik) dan pemilik dana sesuai dengan porsi modal masing-masing, selanjutnya bagian hasil investasi setelah dikurangi untuk pengelola dana (sebagai musytarik) tersebut dibagi 
Sri Handayani

antara pengelola dana (sebagai mudlârib) dengan pemilik dana sesuai dengan nisbah yang disepakati. ${ }^{19}$

Untuk perbandingan perlakuan akuntansi antara mudlârabah muthlaqah dan mudlârabah musyarakah dalam disajikan dalam bentuk contoh kasus: " Tuan Abdul disetujui mendapatkan pembiayaan modal dari bank Istiqomah sebesar Rp 8.000.000,- dan Tuan Abdul juga menyertakan dananya sebesar Rp 2.000.000,- sehingga total dana

\begin{tabular}{|c|c|c|}
\hline Catatan akuntansi Pemilik dana & Transaksi & Pengelola dana (mudharib) \\
\hline 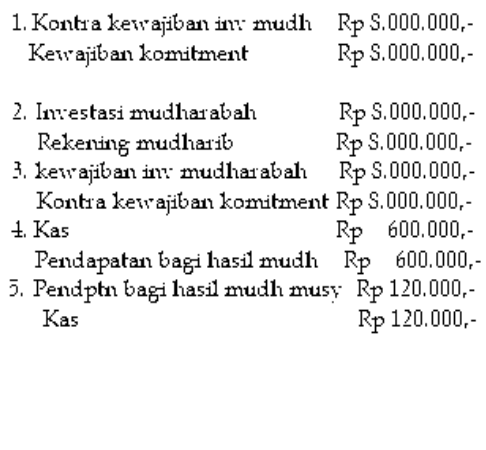 & $\begin{array}{l}\text { Pada saat disetujui } \\
\text { investasi mudharabah } \\
\text { Pada saat pembayaran } \\
\text { dana dan penyetoran dana } \\
\text { dari pilhak mudharib total } \\
\text { dana investasi Rp } \\
10.000 .000 \text { r- }^{-} \\
\text {Diperoleh hasil dari usaha } \\
\text { sebesar } \mathrm{R}_{\mathrm{p}} 1.000 .000\end{array}$ & $\begin{array}{l}\text { Tidak ada jurnal } \\
\text { Kas Rp } S .000 .000 r^{-} \\
\text {Dana syirkalh temporer } \\
\text { Rp } 5.000 .000 r^{-} \\
\text {Kas Rp 2.000.000,- } \\
\text { Dana syirkalh temporer } \\
\text { Rp 2.000.000,- } \\
\text { Hak pilhak ke-3 atas bagi hasil } \\
\text { Rp 600.000,- } \\
\text { Kas Rp } 600.000 r^{-} \\
\text {Kas Rp } 120.000 r^{-} \\
\text {Pendptan bagi hasil mudh } \\
\text { musy } \\
\text { Rp 120.000,- } \\
\text { (Musytarik 2 porsi modal } 20 \% \text { ) }\end{array}$ \\
\hline
\end{tabular}

untuk dikelola sebesar $\mathrm{Rp}$ 10.000.000,- perbandingan nisbah bagi hasil prinsip mudlârabah 60 ( pemilik dana) dan 40 untuk pengelola dana sedangkan prinsip musyarakah sesuai perbandingan modal yang disetor.

Dari alur catatan di atas untuk jurnal 1 s/ d 4 merupakan jurnal akuntansi mudlârabah mutlhlaqah, sedangkan akuntansi mudlârabah musytarakah no 1 s/ d 5 karena didalam investasi usaha pihak mudlarib menyertakan dananya sehingga pembagian hasil usaha menggunakan akad musytarakah. Pihak mudlârib mendapatkan bagi hasil karena menjadi musytarik akibat penyertaan dana dalam investasi usahanya. Dalam kasus ini pihak musytarik (pengelola dana) mendapatkan porsi $20 \%$ karena modal yang menyertakannya sebesar Rp 2.000.000/ Rp 10.000.000,-

19|AI, Standar A kuntansi Keuangan., hlm. 4 
P erbandingan P erlakuan A kuntansi

\section{Penutup}

Perbedaan perlakuan akuntansi mudlârabah muthlaqah dan akuntansi mudlârabah musytarakah terletak pada perlakuan entitas yang menyertainya. Pada akuntansi mudlârabah muthlaqah pembagian hasil usaha sesuai dengan nisbah yang disepakatinya, sedangkan dalam akuntansi mudlarabah musytarakah perbedaan terletak pada penyertaan dana dari pihak pengelola dana sehingga akad yang digunakan adalah akad musyarakah, sedangkan dana yang berasal dari pemilik dana (shâhib al-mâl) menggunakan akad mudlârabah. Jika pemilik dana memberikan batasan dalam pengelolalaan mengenai tempat atau jenis atau cara pengelolaan maka menggunakan akuntansi muqayyadah dan pencatatannya sama dengan akuntansi mudlârabah muthlaqah.

Dengan demikian, mengetahui perbedaan perlakuan akuntansi yang benar, diharapkan laporan yang dihasilkan dapat dipergunakan sebagai pertimbangan pengambilan keputusan dalam berbagai pilihan alternatif ekonomi.

\section{D aftar Pustaka}

AICPA. Statement of the Accounting Principles Board, dalam Intermediet A ccounting, ed. Zaki Baridwan. Yogyakarta: BPFE, 2005.

Algaoud, Latifa M. dan Lewis, Mervyn K. Perbankan Syariah Prinsip, Praktik, Prospek. Jakarta: Serambi, 2005.

Chapra, M.U. Towards a Just M onetary System, Leicester: Islamic Foundation, dalam Perbankan Syariah Prinsip, Praktik, Prospek, ed. Latifa M. Algaoud dan Mervyn K. Lewis. Jakarta: Serambi, 2005.

Ikatan A kuntan Indonesia. Standar A kuntansi Keuangan, (kerangka Dasar penyusunan dan penyajian laporan Keuangan), Jakarta: Salemba Empat, 2009.

--------. Standar A kuntansi Keuangan, PSAK No 105 A kuntansi M udharabah. Jakarta: Salemba Empat, 2009Mulyadi, Sistem A kuntansi. Jakarta: Salemba Empat, 2001

Nikolai dan Bazley. Intermediate A ccounting, Edition 9. USA: Thomsons South-Western, 2002. 
Sri Handayani

Triyuwono, Iwans. Perspektif, M etodologi, dan Teori A kuntansi Syariah. Jakarta: PT Raja Grafindo Persada, 2006

Wiroso, Pengantar Akuntansi Syariah dan Laporan Keuangan Bank Syariah, makalah ToT Perbankan Syariah Universitas Airlangga Surabaya, 2010

Zaki Baridwan, Intermediet A ccounting, Yogyakarta: BPFE, 2005 